Институт за класични студии

Универзитет „Св. Кирил и Методиј“

Скопје

\title{
ФОРМИТЕ НА ГЕНИТИВ СИНГУЛАР ОД ИМИҢА СО ТЕМАТСКА ДЕКЛИНАЦИЈА НА НАТПИСИ ОД ЛИНКЕСТИДА, ПЕЛАГОНИЈА, ДЕРИОП И ЛИХНИД
}

\begin{abstract}
Ancтракт: Предмет на истражување во овој труд се формите на генитив сингулар од имиња со тематска деклинација на натписите од Линкестида, Пелагонија, Дериоп и Лихнид. Анализата, која што беше направена на корпусот натписи објавени во изданието Inscriptiones Graecae X.2.2, покажа дека вообичаено овие форми завршуваат на -ov, но сепак се среќаваат и мал број примери на -оıо. Имајќи предвид дека формите на -оло се јавуваат на доцнежни натписи од 2,3 в. н.е. и од друга страна имајќи го предвид фактот дека завршокот -оıo е поархаичен од завршокот - ov се поставува прашањето, на што се должи појавата на ваквите форми. Направеното истражување упатува на тоа дека компаративната морфолошка и семантичка анализа на формите на -оıо и формите на -ov може да даде релевантни податоци во однос на ова прашање.
\end{abstract}

\section{Увод}

Имињата со тематска деклинација во грчкиот јазик во генитив сингулар не завршуваат на -оৎ како имињата со атематска деклинација. Кај нив уште во предмикенскиот период протоиндоевропската именска наставка *-es/-os/-s била заменета со заменската *-syo. Завршокот/-oyyo/, -oıo (< п.и.е. *-o-syo) е добро потврден во микенскиот грчки, на плочките испишани со линеарно Бе писмо и во хомерската епска поезија. Но, овој завршок веќе во архаичниот период од грчкиот јазик се развил во /-o:/, што на најстарите натписи напишани со грчки алфабет било обележувано како $O$. Подоцна, по воведувањето на јонскиот алфабет, се забележува дека завршокот /-o:/, останал неизменет во северо-западното којне, дорскиот, бојотскиот, лезбоскиот дијалект и се бележел со $\Omega$, а во атичкиот, јонскиот, тесалскиот дијалект се развил во /-o:/, што се бележело со $O Y$. Генитивските форми на -оюо сепак и понатаму продолжиле да се употребуваат. Во Тесалија, во областите Пелазгиотида и Перајбија, завршокот -оло се користел на сите видови натписи сѐ до 2 в. пр. н.е., а во другите делови од Грција и секаде каде што се 
зборувало на грчки, завршокот -оло се јавува на натписи во стих, дури и во времето на римското царство. ${ }^{1}$

Јазикот на грчките натписи од 2, 3 в. н.е. од Линкестида, Пелагонија, Дериоп, Лихнид, области кои ѝ припаѓаат на Горна Македонија, ги покажува характеристиките на атичко-јонското којне типично за тој период. ${ }^{2}$ Така што формите на генитив сингулар од имињата со тематска деклинација вообичаено завршуваат на -ov. Сепак, на неколку натписи се јавуваат и форми на -оюо. Целта на истражувањето направено за потребите на овој труд беше да се утврдат околностите во кои се употребува едниот или другиот завршок. ${ }^{3}$

Истражувањето беше направено на корпусот натписи објавени во изданието Inscriptiones Graecae X.2.2. Ова се натписи од областите Линкестида, Пелагонија, Дериоп, Лихнид. Поголемиот дел од нив се од римскиот период, а помал број натписи има и од времето пред доаѓњето на Римјаните на територијата на Горна Македонија. По својата содржина и функција тие се разновидни: надгробни натписи, почесни натписи, посвети, декрети и го одразуваат подеднакво и јавниот и приватниот живот на населението.

\section{Морфолошка и семантичка анализа на формите на -оv}

Формите на -ov се среќаваат на натписи од сите локалитети. Најстариот пример во корпусот натписи IG X.2.2, ако е правилно

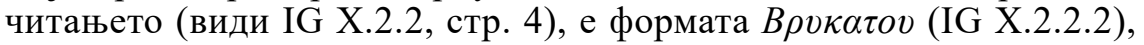
надгробен споменик од 350 г. пр.н.е., од областа Линкестида.

Формите на -ov во најголема мера се генитиви од машки лич-

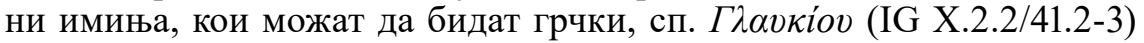

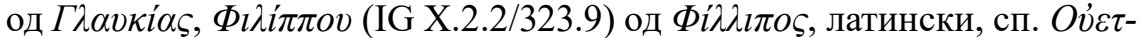

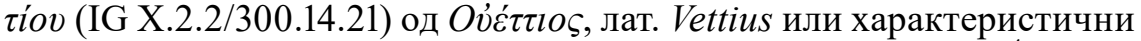

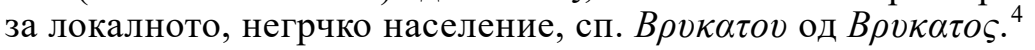

Покрај тоа, се среќаваат и примери од имиња на месеци, сп.

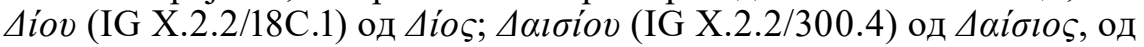

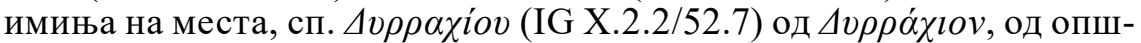

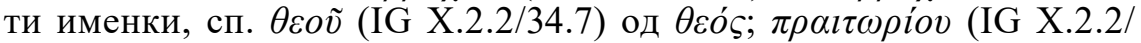

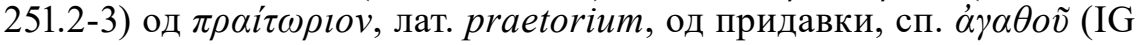

${ }^{1}$ Buck (1955) 88; Chantraine (1967) 38; Blümel (1982) 240 -243; Sihler (1995) 259-260; Colvin (2007) 43.

2 За развојот на атичкото којне, за улогата на македонската кралска куќа во неговото распространување и за неговите главни характеристики во римскиот период, види Mc Lean (2009) 346-355; Colvin (2007) 65-69; Adrados (2005) 180-184, 192-196; Horrocks (2010) 80-84, 88-90, 133-137, 160-165.

3 Делумна презентација на ова истражување, но само за формите на -оюо, беше направена преку постер на 14-тиот Меѓународен конгрес за грчка и латинска епиграфика одржан во Берлин, 2012.

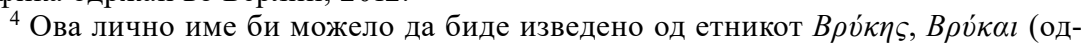

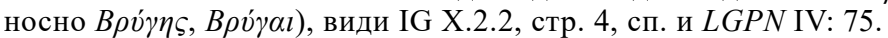


X.2.2/159.1) од $\dot{\alpha} \gamma \alpha \theta o ́ \varsigma$, од глаголски партиципи, сп. $\pi \omega \lambda o v \mu \varepsilon ́ v o v ~(\mathrm{IG}$ X.2.2/323.4) од $\pi \omega \lambda \dot{\varepsilon} \omega$, од заменки, сп. є́кعívov (IG X.2.2/83.5) од

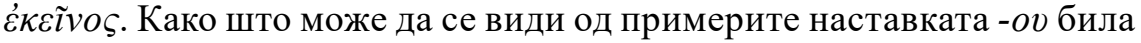
характеристична и за римските имиња и за латинските заемки.

Што се однесува до семантичките улоги, формите на генитив сингулар на -ov, и во овој поглед покажуваат разновидност. По бројност доминираат формите, што искажуваат потекло, и во таа смисла, во рамките на ономастичката формула имаат функција на патронимик. Ваквите примери можат да бидат придружени со именките $v i$ -

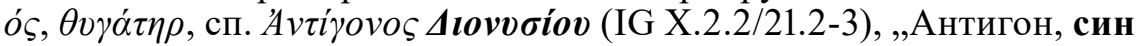

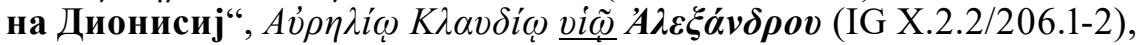

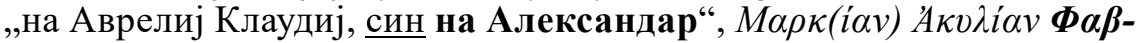

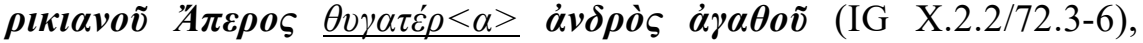
„Маркија Акилија, ќерка на Фабрикиан Апер, добар човек“.

Често се среќаваат и синтагми со именки како $\mu \eta \dot{\tau} \rho, \gamma v v \eta ́$, $\sigma v ́ \mu \beta \iota о \varsigma$, во кои со генитивот се означува семејна поврзаност, сп.

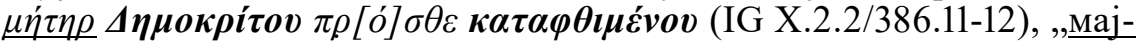

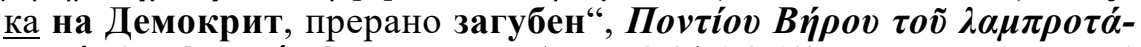

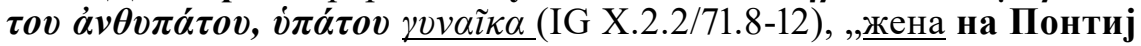

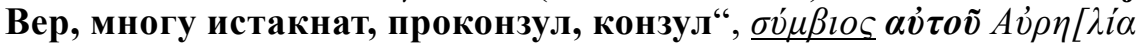
Av] $\tau \imath \gamma o ́ v \alpha$ (IG X.2.2/174.6-7), „Аврелија Антигона, негова сопруга“.

Има примери каде што генитивот ја врши семантичката улога

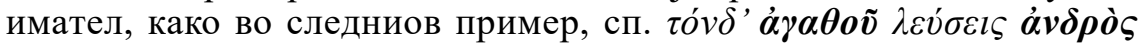
$\underline{\tau \alpha ́} \varphi$ ov $(\mathrm{IG} \mathrm{X.2.2/159.1),} \mathrm{„Го} \mathrm{гледаш} \mathrm{гробот} \mathrm{на} \mathrm{добар} \mathrm{човек“.} \mathrm{Има}$ примери каде што генитивот ја врши семантичката улога агенс, сп. $\kappa \alpha \tau \grave{\alpha} \underline{\kappa \varepsilon} \lambda \varepsilon v \sigma l v \boldsymbol{\tau} \tilde{\boldsymbol{\eta}} \varsigma \boldsymbol{\theta} \boldsymbol{\varepsilon} о \tilde{\boldsymbol{v}}$ (IG X.2.2/34.6-7), „по заповед на божицата“

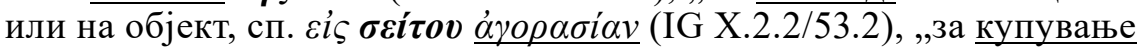

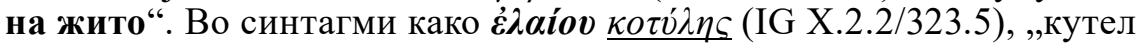
масло“, генитивот означува содржина, исполнетост.

На натписите се забележуваат повеќе примери, каде што генитивот на -ov ја дополнува синтагмата $\mu v \eta \dot{\mu} \eta \varsigma \chi \alpha \dot{\alpha} \rho \imath v$, ,во спомен

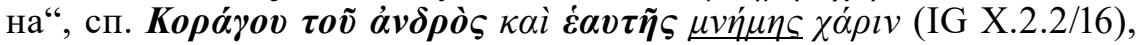

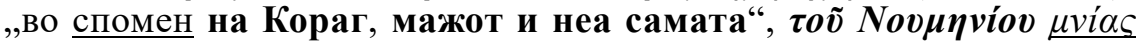
$\chi \alpha ́ \rho \imath v$ (IG X.2.2/10.6), „во спомен на Нумениј“. Во овој случај генитивот има функција на партитив, односно искажува делумна засегнатост.

Кај имињата на месеците формите на генитив искажуваат

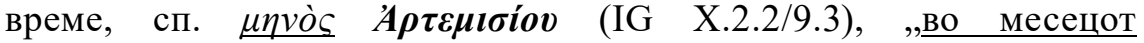
Артемисиј“. А темпорално значење имаат и синтагмите составени од глаголски партицип и лично име, кои се вообичаени на

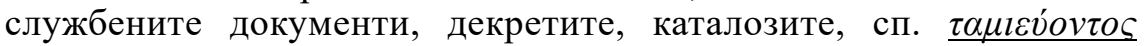

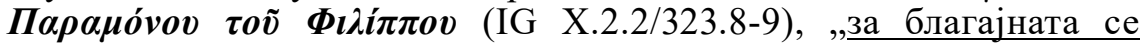
грижеше Парамон, син на Филип“.

Формите на -ov исто така доаѓаат и со различни предлози, сп. $\dot{\alpha} \pi \grave{o} \Delta v \rho \rho \alpha \chi i o v(\mathrm{IG}$ X.2.2/52.7), „од Дурахиј“, $\mu \varepsilon \tau \grave{\alpha} \tau о \tilde{v} \sigma v \beta i ́ o v\{\sigma v \mu \beta i$ ov\} (IG X.2.2/240.5), „со сопругот“. 


\section{Морфолошка и семантичка анализа на формите на -оло}

Во корпусот натписи IG X.2.2 се среќаваат и неколку форми на генитив сингулар на -оло. Сите примери се од 2, 3 в.н.е., односно од римскиот период.

На натписот IG X.2.2/26, надгробен споменик пронајден во

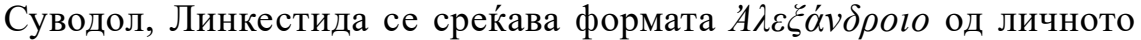
име $A \lambda \dot{\varepsilon} \xi \alpha v \delta \rho o \varsigma$. Натписот е само делумно зачуван, но сепак може да се забележи дека формата во генитив следи по едно -оৎ, кое може да се претпостави дека е завршок од друго име во номинатив. Ова значи дека генитивот има функција на патронимик. Ономастичката формула составена од лично име во номинатив и име на такото (или мајката) во генитив била типична за Македонците и Грците. (Рараzoglu, 1955: 353 и понатаму).

Личното име Александар е документирано индиректно преку женската варијанта $A \lambda \varepsilon \xi \dot{\alpha} \alpha \delta \rho \alpha$, уште на микенските плочки, сп. $a-r e-$

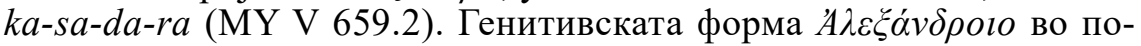
микенскиот период се среќава и во книжевни текстови и на натписи. Најстарите примери од книжевноста се од Хомеровата „Илијада“", а се однесуваат на Александар, синот на Пријам, сп. $\mu \tilde{v} \theta$ ov $A \lambda \varepsilon-$

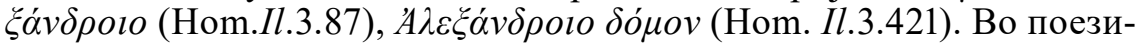
јата забележани се примери, кои се однесуваат на Александар, кралот на Македонците, сп. во епиграм од Адај, $\tau \dot{v} \mu \beta o v A \lambda \varepsilon \xi \dot{\alpha} v \delta \rho o \imath o$

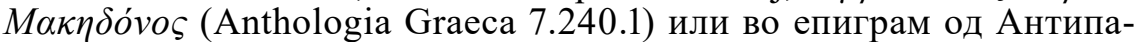

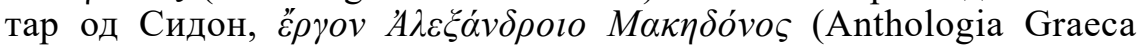

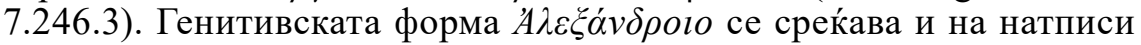

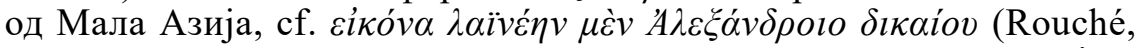

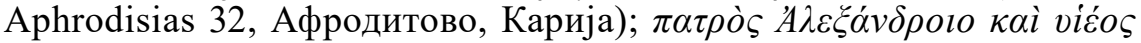

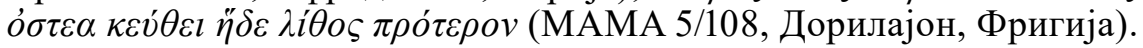

Епиграфскиот материјал потврдува дека личното име Александар било особено популарно во областите на Македонија (види $L G P N$ IV, стр. 14-17). Примери има и од областа Линкестида, сп. IG X.2.2/40; IG X.2.2/61; IG X.2.2/96; IG X.2.2/122; IG X.2.2/136. Позната историска личност од оваа област е $A \lambda \dot{\varepsilon} \dot{\xi} \alpha \nu \delta \rho o \varsigma \Lambda v \gamma \kappa \eta \sigma \tau \dot{\zeta}$, син на Аероп, брат на Арабај и Херомен и зет на Антипатар. Бил современик на Александар Македонски и генерал во неговата војска (Tataki, 1998: 201).

Што се однесува до натписот IG X.2.2/26, тука, освен генитивот $A \lambda \varepsilon \xi \dot{\alpha} \alpha \delta \rho \rho o ю$ нема други форми на генитив сингулар од имиња со тематска деклинација. Во третиот и четвртиот ред се јавуваат именската форма $\dot{\alpha} \lambda \dot{\alpha} \chi \omega$, дат. сингулар од $\ddot{\alpha} \lambda o \chi o \varsigma$, „сопруга“, наспроти вообичаената за натписите, именка со истото значење $\sigma \dot{\mu} \mu \beta ь \varsigma$ и глаголската форма $\mu і \dot{\mu} v \eta \sigma \kappa \varepsilon$ од глаголот $\mu \imath \mu v \dot{\sigma} \sigma \kappa \omega$, ,си припомнувам, се сеќавам“. Употребата на овие зборови е вообичаена и на други надгробни натписи во стих, од другите региони, каде што се 
зборувало и пишувало на грчки, сп. IK Klaoudiopolis 77, Клаудиополис, Битинија:

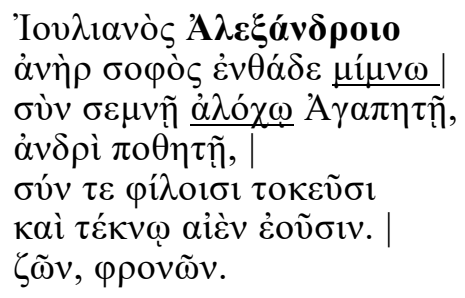

Врз основа на ова може да се претпостави дека текстот од натписот IG X.2.2/26 од Линкестида бил исто така поетски (види IG X.2.2, стр. 15).

Натписот IG X.2.2/27 од Суводол, Линкестида е надгробен споменик, на кој може да се прочитаат дваесетина реда од поема составена од хомерски стихови. Песната ја искажува тагата на тат-

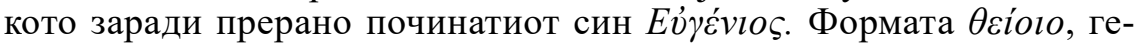
нитив сингулар од придавката $\theta \varepsilon \tilde{\imath} о \varsigma$, „божествен, свет, надчовечки“ се среќава во четвртиот ред. Стихот е преземен од Хомеровата „Одисеја“, сп.:

\section{IG X.2.2/27.4-6}

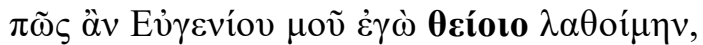

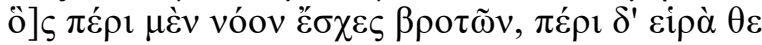
oĩ] $\sigma \mathrm{t} v^{\circ} \ldots$.

и

Hom.Od.1.65-67

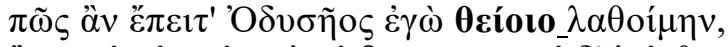

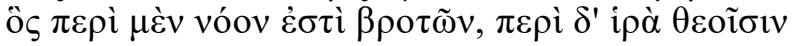

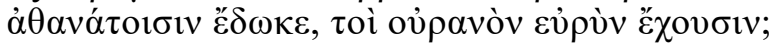
„Како ќе сум го заборавел јас Одисеја дивен, најумен што е сред љуѓето тој и што најмногу жртви дал на бесмртните бози, што ширното небо го држат?““ (преп. Петрушевски, 2008)

Придавката $\theta \varepsilon i \tilde{\varsigma}$ е вообичаен епитет на Одисеј, но исто така

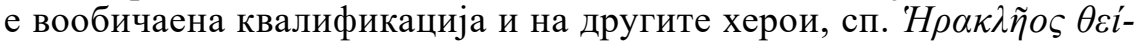

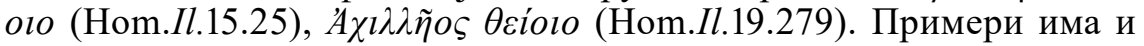

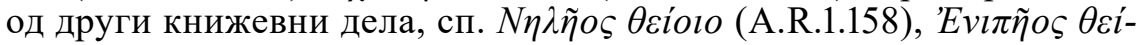

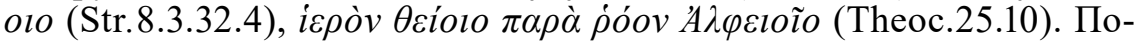

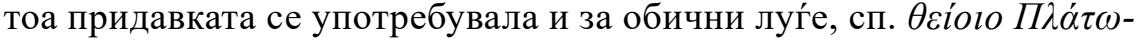
vos (Anthologia Graeca (Mel.) 4.1.47). На натписот IG X.2.2/27 освен формата $\theta$ cioıo се среќаваат четири форми на генитив сингулар на

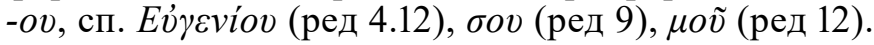


Натписот IG X.2.2/265, пронајден во Небрегово, Пелагонија е надгробен споменик, што го направила $N \alpha \dot{v} \alpha$ во спомен на нејзиниот маж, нејзиното дете, нејзиниот внук и на самата себеси. Текстот на натписот е типичен за ваков тип на споменици, но зборот vi $\omega v o ́ \varsigma$, „внук“ е употребен во генитив како vicvoĩo, напишано v́wvoĩo, со графема $v$ наместо $v \imath$ (Mc Lean, 2009: 349). Генитивската форма vi $\omega v o \tilde{o}$ е забележана кај Хомер и кај други подоцнежни автори, сп.:

IG X.2.2/265

$\dot{\alpha} v \delta \rho o ̀ \varsigma \alpha$ aioṽ $\pi \alpha 1 \delta o ́ \varsigma \tau \varepsilon$

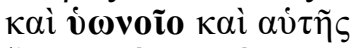

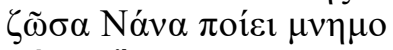

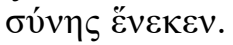

И

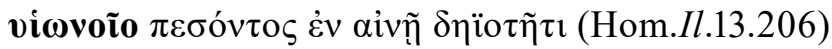

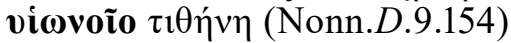

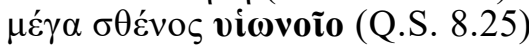

Ако го споредиме овој натпис со други натписи со слична содржина ќе забележиме дека глаголската форма гласи $\pi о i \varepsilon l$ наместо

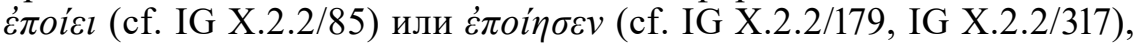

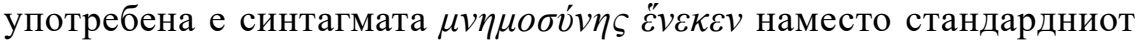

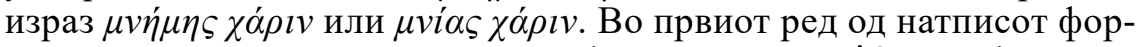
мата за генитив сингулар од посвојната придавка є́ó, , „ввој, негов“

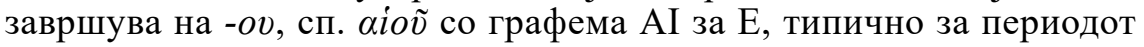
од кој доаѓа натписот (Ricl, 1994: 154, Mc Lean, 2009: 349). Имињата на починатите не се спомнуваат, но Nóv $\alpha$ е фригиско име и често се среќава на натписи од Мала Азија (сп. IG X.2.2, стр. 10; Zgusta, 1964: 346-347).

Уште една форма на генитив сингулар на -оюо се среќава во првиот ред од натписот IG X.2.2/292, Дебреште, Пелагонија, сп.:

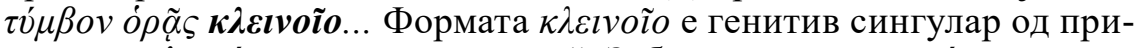
давката $\kappa \lambda \varepsilon \imath v o ́ \varsigma$, „познат, прочуен“. Забележани се повеќе примери

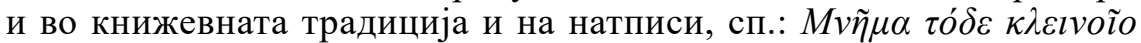

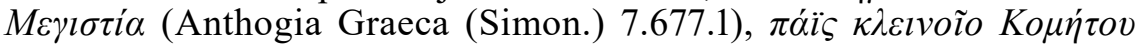

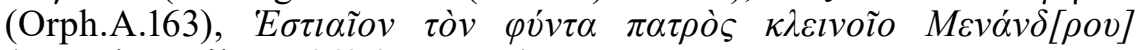
(McCabe, Miletos 463.9, Милет). На натписите е потврдено и лично

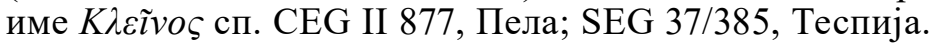

Иако надгробниот споменик е оштетен, сепак се забележуваат елементи од поетски јазик, како на пр. $\pi \rho \alpha \pi i \delta \varepsilon \sigma \sigma l$, дат. плурал на - $\varepsilon \sigma \sigma l$ од именката $\pi \rho \alpha \pi i \delta \varepsilon \varsigma$, „дијафрагма, разум, ум, срце“, епска форма наместо вообичаената $\pi \rho \alpha \pi i \sigma l v$, сп. $\delta \tilde{\omega} \mu \alpha \pi \varepsilon \rho \imath \kappa \lambda v \tau \dot{\varsigma} \varsigma \dot{\alpha} \mu \varphi \imath \gamma v \dot{\varepsilon} \varepsilon l \varsigma$

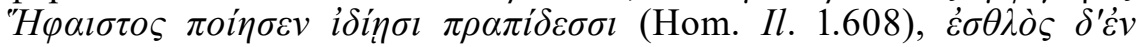

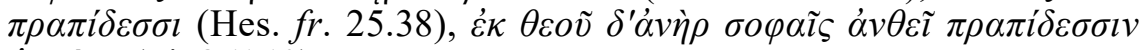

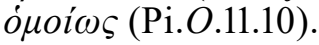


На натписот IG X.2.2/331, Чепигово, Дериоп се среќава фор-

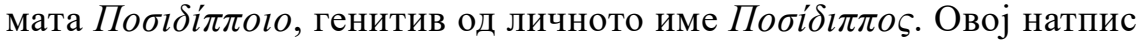
за разлика од другите, на кои има форми на -оюо е почесен натпис.

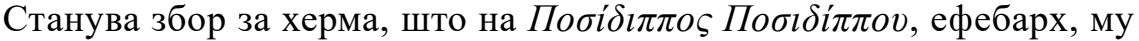
ја подигнале и посветиле неговите пријатели ефеби. Натписот е во метар, елегиски дистих, сп.:

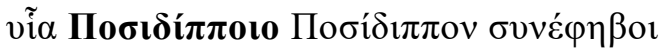

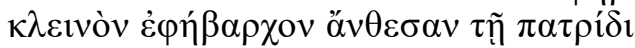

Но, самиот текст не е особено поетски. Сепак, покрај генитивска форма -оlo и акузативот vĩ од именката viv́s, „син“ упатува

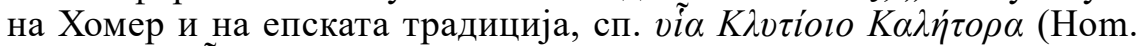

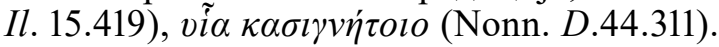

И покрај тоа што, бројот на форми на -ово е мал, може да се забележи дека примерите се од три категории зборови: машки лични имиња, именки и придавки. Но, ниедна од формите не е заемка од латинскиот јазик.

И од семантички аспект се забележува разновидност, иако помала во поглед на формите на -ov. Има примери на генитив што искажува потекло, патронимик, без зборот „син“, сп. А $A \lambda \varepsilon \xi \dot{\alpha} v \delta \rho о \imath о$

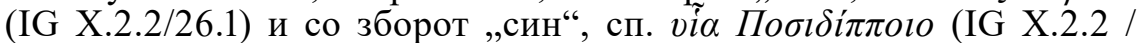
331.1). Има примери на генитив што означува делумна засегнатост, партитив, со глагол, што значи „се сеќавам / заборавам“, односно со именка со истото значење, сп. $\theta$ cíoıo (IG X.2.2 / 27.4), објект на глаголот $\lambda \alpha v \theta \dot{\alpha} v o \mu \alpha l$ и $\dot{\omega} \omega v o \check{o}$ (IG X.2.2/265.2), со именката $\mu \nu \eta \mu о-$ $\sigma v ́ v \eta$. А, еден од примерите е генитив што ја врши семантичката

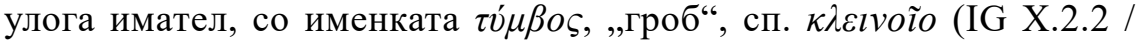
292.1).

\section{Заклучок}

Направената морфолошка и семантичка анализа на формите на генитив од имиња со тематска деклинација, и споредбата помеѓу генитивите на - $o v$ и генитивите на -оло покажува дека завршокот -ov бил вообичаен кај сите категории зборови, вклучително и кај заемките од латинскиот јазик, односно имињата на римските граѓани. Од друга страна, иако бројот на примери е исклучително мал, може да се забележи дека завршокот -оло исто така се среќава кај различни категории зборови, но не и кај заемки од латинскиот јазик, односно кај имиња на римските граѓани. Формите на генитив сингулар на -ov покажуваат широк опсег на семантички значења, разновидност од синтагми и фрази, во зависност од намената на епиграфскиот споменик. Опсегот на значења кај формите на генитив сингулар на -оло е далеку помал, односно потврдени се само три значења: потекло, присвојност и партитив. Се разбира, имајќи го предвид малиот број на форми, фактот што нема примери со аблативско значење не мора да биде од важност. 
Што се однесува до контекстот, формите на -оюо се јавуваат или во експлицитен поетски контекст, каков што има на пример, натписот IG X.2.2/27, кој претставува поема составена од дваесетина хомерски стихови или во контекст кој асоцира на посебниот поетски јазик преку употреба на зборови характеристични за епската или лирската поезија, а не за стандардните епиграфски формули, сп. $\dot{\alpha} \lambda \dot{o} \chi \omega$, дат. синг. од $\ddot{\alpha} \lambda o \chi o \varsigma$, ,сопруга“" наместо вообичаеното $\sigma \dot{v} \mu \beta$ -

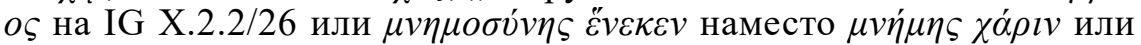
$\mu v i \alpha \varsigma \chi \dot{\alpha} \rho \imath v$ на IG X.2.2/265. Дури и на еден натпис како IG X.2.2/331, единствениот кој не е надгробен споменик, туку почесен, и кој содржи прилично стандардна формулација за ваков тип на споменици, употребена е формата ví $\alpha$, акуз. синг. од постарата атематска флексија на именката viós, „син“ наместо формата vióv од тематската флексија на истата именка.

Се разбира во поетски контекст се среќаваат и формите на -ov, па дури и паралелно со формите на -оюо на ист натпис, сп. IG X.2.2/27, IG X.2.2/265, но тоа е во крајна линија едно од најтипичните лингвистички обележја и на хомерскиот јазик. ${ }^{5}$ Она што треба да се истакне е дека сите форми на генитив сингулар на -оло забележани во корпусот натписи IG X.2.2 се забележани како такви и во грчката книжевност или на натписи од другите региони каде што се употребувал грчкиот јазик.

Спомениците од камен биле изработувани во каменорезбарски работилници. Се поставува прашањето кој ги составувал самите текстови за натписите? Тоа можел да биде каменорезецот или лицето што го нарачало споменикот или пак можеби имало специјализирани и образувани писари (Mc Lean, 2009: 10-11, Šašel-Kos 2012: 514). Во секој случај, присуството на форми генитив сингулар на -оло заедно со други форми типични за поезијата, на натписите од 2, 3 в. н.е. во областите Линкестида, Пелагонија, Дериоп се должи на распространетото влијание на грчката култура. Анализата потврдува дека овие форми и во Горна Македонија, како и во сите други региони каде што се зборувало и пишувало на грчки, се чувствувале како важно обележје на поетскиот јазик. Важно е да се нагласи дека личните имиња, кои може да се поврзат со формите на -оло, како имиња на починатите лица, на кои споменикот им бил посветен или пак како имиња на лицата кои го подигнале споменикот, не се само

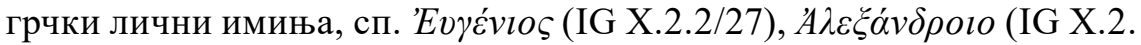

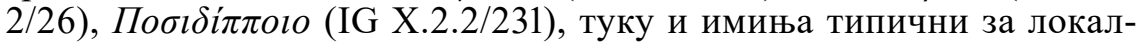

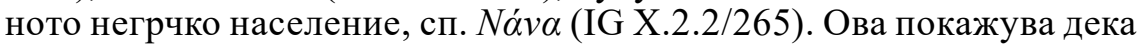
употребата на ваквите форми од една страна може да се сфати како начин да се покаже ученост, културен статус, можеби дури и мода. Не е исклучено и постоењето и преземањето на готови шаблони при составувањето на текстовите, особено за надгробните споменици.

${ }^{5}$ Според анализата на Шантрен во „Илијада“ и „Одисеја“ има вкупно 1881 пример на -оv и 1801 пример на -оıо, види Chantraine, 1973: 165. 
Но, од друга страна не може да се одбегне впечатокот дека нивната употреба, била и начин да се персонализира текстот и да се направи споменикот различен од другите. Типичен во оваа смисла е натписот IG X.2.2/265 на споменик, кој е подигнат од жена, што го носи името $N \alpha \dot{v} \alpha$.

\section{БИБЛИОГРАФИЈА}

Adrados, F. R. (2005). A History of the Greek Language. Leiden - Boston: Brill.

Blümel, W. (1982). Die aiolischen Dialekte, Ergänzungshefte zur ZVS Nr. 30, Göttingen.

Buck, C.D. (1955). The Greek Dialects. Chicago: The University of Chicago Press.

Chantraine, P. (1967). Morphologie historique du grec. Paris: Éditions Klincksieck.

Chantraine, P. (1973). Grammaire homérique I. Paris: Éditions Klincksieck.

Colvin, S. (2007). A Historical Greek Reader. Myceaean to the Koiné. Oxford: Oxford University Press.

Хомер, „Одисеја“, од старогрчкиот оригинал превел и препеал М. Д. Петрушевски, прир. К. Петрушевска и В. Петрушевски), Скопје: Магор, 2008.

Horrocks, G. (2010). Greek: A History of the Language and its Speakes. Chichester, West Sussex, UK: Wiley - Blackwell.

IG X.2.2 = Papazoglu, F. et al., eds. (1999). Inscriptiones Graecae Epiri, Macedoniae, Thraciae, Scythiae (Volumen X). Inscriptiones Macedoniae (Pars II). Inscriptiones Macedoniae Septentrionalis (Fasciculus II). Inscriptiones Lyncestidis, Heracleae, Pelagoniae, Derriopi, Lychnidi (Sectio 1). Berolini - Novi Eboraci: Gualterus de Gruyter.

LGPN IV = Fraser, P.M., Mattews, E. et al., eds. (2005). A Lexicon of Greek Personal Names. Oxford: Clarendon Press.

Mc Lean, B.H. (2009). An Introduction to Greek Epigraphy of the Hellenistic and Roman Periods from Alexander the Great down to the Reign of Constantine (323 B.C. - A.D. 337). 5th edn. Ann Arbor: The University of Michigan Press.

Papazoglou, F. (1955). O onomastickoj formuli kod Makedonaca u Rimsko doba. $\check{Z} A$ 5 , pp. 350-370.

Papazoglou, F. (1988). Les villes de Macedoine à l'époque romaine, BCH Suppl. XVI, Paris.

Ricl, M. (1994). New Greek Inscriptions from Pelagonia and Derriopos. ZPE 101, pp. 151-163.

Sihler, A.L. (1995). New Comparative Grammar of Greek and Latin. New York - Oxford: Oxford University Press.

Šašel-Kos, M. (2012). A Glimpse into Stonecutter's Workshops in Scupi, Upper Moesia. In: A. Donati and G. Poma, eds., L'Officina epigrafica Romana in ricordo di Giancarlo Susini. Epigrafia \& Antichità No. 30. Faenza: Fratelli Lega Editori, pp. 507-524.

Tataki A.B. (1998). Macedonias Abroad. Meletemata 26. Paris: Diffusion de Boccard.

Zgusta, L. (1964). Kleinasiatische Personennamen. Prag: Verlag der Tschechoslowakischen Akademie der Wissenschaften. 
Elena Džukeska

Institute of Classical Studies, Faculty of Philosophy

University of Sts. Cyril and Methodius, Skopje

elena.dzukeska@gmail.com

\section{GENITIVE SINGULAR FORMS OF THEMATIC NOMINALS ON GREEK INSCRIPTIONS FROM LYNCESTIS, PELAGONIA, DERRIOPOS AND LYCHNIDOS}

\section{SUMMARY}

This paper studies the genitive singular forms of thematic nominals on Greek inscriptions from Lyncestis, Pelagonia, Derriopos and Lychnidos. The analysis performed on the corpus of inscriptions published in the edition Inscriptiones Graecae X.2.2, has shown that these forms usually end in -ov, but there are also few forms ending in -olo. Bearing in mind on one hand that all forms in -olo are found on late inscriptions from the Roman period (2nd and 3rd century AD) and on the other, the fact that the ending -oio is more archaic than the ending -ov one has to ask the question, what is the reason for occurrence of such forms.

The morphological and semantic analysis has shown that forms in -olo in the regions of Lyncestis, Pelagonia, Derriopos as elsewhere in late antiquity were felt as a significant feature of the poetic Greek language and in this sense as a way to show knowledge and education. But, using genitive forms in -olo (and other forms typical for the poetic language) was also a self-sufficient linguistic device for personalization of the inscription and the monument, an opportunity to make it different and special.

Key words: genitive singular, thematic declension, Lyncestis, Pelagonia, Derriopos and Lychnidos 